\title{
Knocking on Charon's Door. Andrea Dazzi's Epigram for Julius II, and the Iulius exclusus
}

\author{
FILIPPOMARIA PONTANI
}

A Greek epigram by Andrea Dazzi on the death of Pope Julius II looks like a satire in the fashion of Lucian, Aristophanes, and the Greek Anthology: the wording of this text brings to mind not only Pontano's Charon and, more specifically, some popular polemical texts against Julius, but also Erasmus of Rotterdam's dialogue Iulius exclusus e coelis, with which it shares some startling similarities. ${ }^{*}$

\section{A Florentine poet: Andrea Dazzi}

In February 1513 Niccolò Machiavelli was suspected of taking part in the anti-Medicean conspiracy of Pietro Paolo Boscoli, and sent to jail. The death of Pope Julius II (on the night of 20-21 February 1513) and the subsequent election of Giovanni de' Medici as Pope Leo X on 9 March aroused widespread popular enthusiasm in Florence and led to a general amnesty: two days later Machiavelli had regained his freedom.

In a bitter sonetto caudato written from jail and addressed to Giuliano de' Medici (the son of Lorenzo il Magnifico and the brother of the future pope), the Segretario Fiorentino poked fun at a poetaster named "il Dazzo" (Rime varie 13, 1. 15-17). ${ }^{1}$ Almost forgotten nowadays, Andrea Dazzi (Florence, 1473-1548) was one of the most brilliant pupils of chancellor Marcello Virgilio Adriani, and taught Greek and Latin from his appointment in 1502 in Florence (under Soderini's Republic) and then in Pisa, until an early retirement due to precocious blindness, possi-

* I would like to thank Humanistica Lovaniensia's anonymous reviewers, Federico Tanozzi and Martina Tosello for their help in Lucianic matters, and David Speranzi (Florence), Floriana Amicucci (Ravenna), and Silvia Tebaldi (Bologna) for their help with manuscripts.

${ }^{1}$ A. Corsaro, P. Cosentino et al. (ed.), Niccolò Machiavelli, Scritti in poesia e in prosa (Roma, 2012), 280-282 (1. 9-17): "Dissigli il nome; e lei, per strazïarmi, / mi batté al volto e la bocca mi chiuse, / dicendo: - Niccolò non se', ma il Dazzo, / poiché ha' legato le gambe e i talloni, / e sta' ci incatenato come un pazzo. - / Io gli volevo dar le mie ragioni; / lei mi rispose, e disse: - Va' al barlazzo, / con quella tua commedia in guazzeroni. - / Dàtegli testimoni, / Magnifico Giulian, per l'alto Iddio, / come io non sono il Dazzo, ma sono io." Nothing is known of this "commedia in guazzeroni". 
bly around 1520 . Venerated by his pupils and fellow-citizens (including no less a figure than Pier Vettori), Dazzi was one of the most successful orators, intellectuals and versifiers of his time, and a faithful adherent of the Medici clan (witness his significant participation in the 1515 poetic sylloge known as Lauretum): he was not adversely affected by the fall of the Republic, which may in part explain Machiavelli's hostility. ${ }^{2}$

Indeed, in that same spring of 1513 Dazzi had become so popular as to be entrusted by the powerful Compagnia del Diamante with the organisation of a triumph in ancient Roman garb for the election of Leo X: according to Giorgio Vasari, an ensemble of three chariots, named Erimus, Sumus and Fuimus, and representing Puerizia, Virilità and Senettù personified by a number of young, middle-aged and elderly men, was decorated by outstanding painters such as Jacopo Pontormo and Andrea del Sarto. ${ }^{3}$

Despite Rüdiger's preliminary survey, Dazzi's literary production is still largely understudied: ${ }^{4}$ we lack a reliable chronology and interpretation of his works, most of which - though by no means all extant ones were published in the posthumous Latin Poemata edited by his son Giovanni in $1549 .{ }^{5}$ These embrace a youthful comic-heroic epic called Aeluromyomachia (Battle of Cats and Mice), several love poems, bucolic eclogues, mythological tableaux, long encomiastic elegies, a few sylvae for powerful patrons (including Duke Cosimo I de' Medici and Pope Clement VII), as well as a lot of épigrammes d'occasion: the addressees of the latter, in particular, show the breadth of his acquaintance in high-brow Florentine society of both centuries, from Marsilio

2 See R. Black, Machiavelli (New York, 2013), 78. The bid for Giuliano's favour is the context of Machiavelli's sonnet according to F. Bausi, "Politica e poesia: il Lauretum", Interpres 6 (1985-1986), 214-282, at 269-271. On Dazzi's biography see also C. Vivoli, "Dazzi, Andrea", in Dizionario biografico degli Italiani, vol. 33 (Roma, 1987), 184-186 (subsequently in Enciclopedia Machiavelliana, vol. 1 (Roma, 2014), 385-386). On his appointment in Pisa see a passage of the 1515 letter of Jacopo de' Medici to Lorenzo de' Medici, the nephew of Pope Leo X (Firenze, Biblioteca Riccardiana, ms. 970, f. 1v): see F. Novati, "I codici Trivulzio-Trotti", Giornale storico della letteratura italiana 9 (1887), 137185, at 153: "Cuius [scil. Dactii] licteras quanti facere deceat praeter diuturnum periculum tu ipse ostendisti, qui illum inter Gymnasii Pisani professores honeste merere curaveris."

${ }^{3}$ R. Bettarini, P. Barocchi (ed.), Giorgio Vasari, Vite, vol. 5 (Firenze, 1984), 310.28-33 (Pontormo).

${ }^{4}$ W. Rüdiger, Andreas Dactius aus Florenz (Halle, 1897). See Vivoli 1987 (as in n. 2) and Bausi 1985-1986 (as in n. 1), 270-271.

${ }_{5}^{5}$ Andreae Dactii patricii et academici Florentini Poemata (Florentiae, apud Laurentium Torrentinum, 1549 [USTC 825599]). 
Ficino to Pietro Crinito, from Michele Marullo to Naldo Naldi and Guido Antonio Vespucci, and from Lorenzo il Magnifico to Niccolò Ridolfi. Dazzi's most ambitious poem, titled Virbius, was written precisely in praise of Leo X: we do not know the details of its composition, dissemination and readership, but 31 March 1515 is the date of the dedication copy (Paris, Bibliothèque nationale de France, ms. NAL 460), ${ }^{6}$ and probably also of the parchment codex (Firenze, Biblioteca Riccardiana, ms. 970) carrying a letter of Dazzi's pupil Jacopo de' Medici to the Capitano generale Lorenzo de' Medici (later Duke of Urbino) in praise of Dazzi's skill, loyalty and devotion to the ruling family, and of his officium and pietas.

Dazzi's poetic use of Greek is quite remarkable by the standards of his time, and it embraces two dozen épigrammes d'occasion celebrating the death or the deeds of illustrious colleagues (from Pietro Crinito to Jacopo Nardi), the Aldine editions of Plato and Aristotle, the Italian expedition of Charles $\mathrm{V}$, and other mythological or gnomic themes - the style partly recalls, if in a minor key, the fashion of Dazzi's former teacher (and then rival) Angelo Poliziano, or that of his colleague Scipione Forteguerri. ${ }^{7}$

\section{Dazzi's Greek epigram for Julius II: text and context}

Although this Greek output, scattered throughout the pages of the 1549 Poemata, has until now hardly received any attention, at least one item stands out for its date and its content. I am referring to the witty epigram on the death of Julius II on pages 297-298, written in all likelihood soon after the news had reached Florence, in the weeks of March 1513 when Machiavelli was freed from jail, and Dazzi conceived the Virbius and the grand celebrations for the Compagnia del Diamante. The printed text abounds in mistakes, which - for lack of Greek autographs of Dazzi's poetry (the epigram on Homer on f. 1v of Firenze, Biblioteca Nazionale

\footnotetext{
${ }^{6}$ Once Milano, Biblioteca Ambrosiana, ms. Trotti 479: see C. Pasini, "Dalla biblioteca della famiglia Trivulzio al Fondo Trotti dell'Ambrosiana", Aevum 67 (1993), 647-685, at 666, and above all Novati 1887 (as in n. 2), 151-155 (with further information on Dazzi).

7 See F. Pontani (ed.), Angelo Poliziano, Liber epigrammatum Graecorum (Roma, 2002); Id., "Graeca per Italiae fines. Greek Poetry in Italy from Poliziano to the Present", in S. Weise (ed.), Hellenisti! Altgriechisch als Literatursprache im neuzeitlichen Europa (Stuttgart, 2017), 311-347. A reappraisal of the phenomenon of neualtgriechische Dichtung in Europe will be offered in a forthcoming anthology by F. Pontani, S. Weise (ed.), The Hellenizing Muse (Berlin, 2020).
} 
Centrale, ms. Magl. VII 1213 is not in his hand $)^{8}-$ I hesitate to ascribe to the author, and prefer to consider as mere misprints.

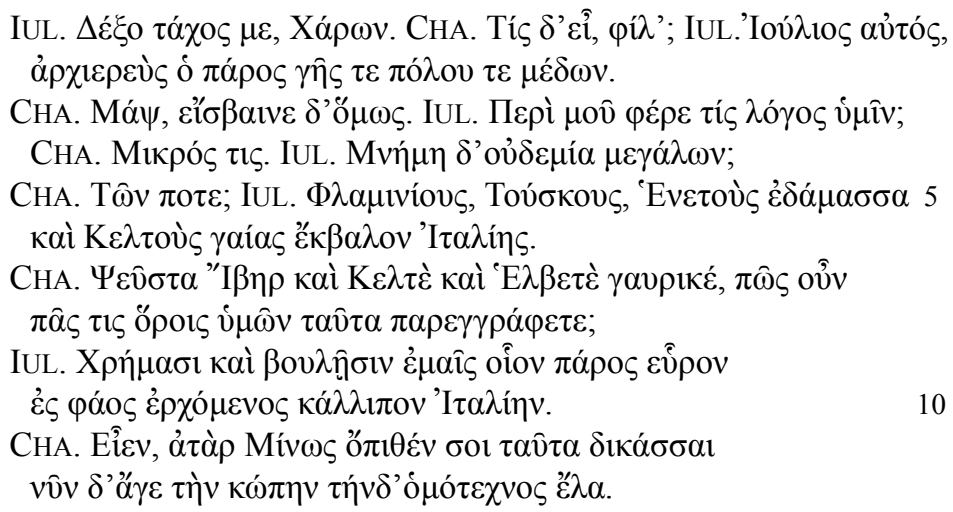

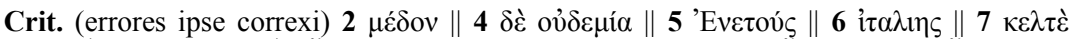

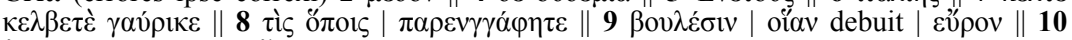

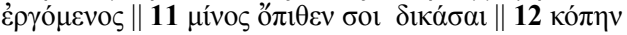

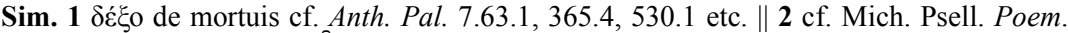

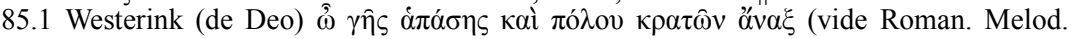

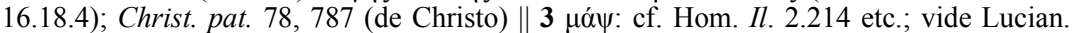

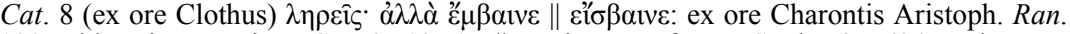

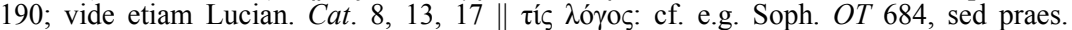

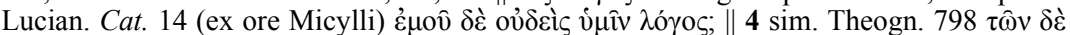

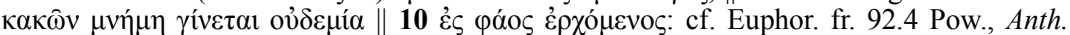

${ }^{8}$ It was written by Giovan Battista di Pierfilippo di Jacopo Gianfigliazzi, possibly one of Dazzi's pupils in his late years (see the note on f. 1r: "Hic liber est Ioannis Baptistae Petri Philippi Iacobi de Gianfigliazziis et amicorum; in sul quale libro io detto Giovambaptista iscrivevo el primo libro di Homero infino al fine per imparar a scrivere Greco cominciando addi 15 di maggio 1544.") A diplomatic transcription of this smart piece:

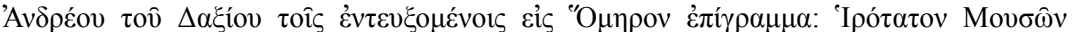

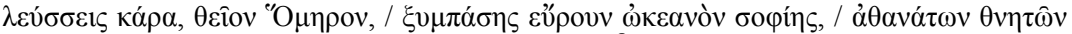

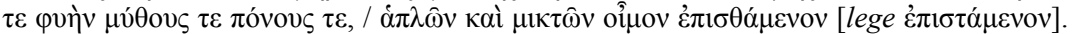

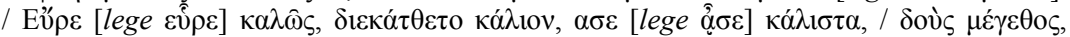

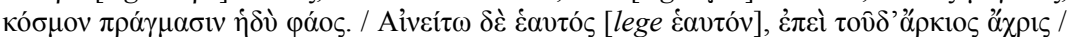

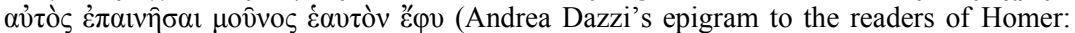
"You see the holy head, the nursling of the Muses, divine Homer, / the fair-flowing ocean of all wisdom, / him who knows the nature, the stories and the toils of both mortals and immortals, / and the path of both simple and complex things. / His invention was good, his disposition even better, his song was perfect, / for he gave things greatness, order and sweet light. / May he praise himself, for until now he alone is by nature / good enough to sing his own praise"). Furthermore, Dazzi's epigram on the Italian translation of Sophocles' Electra by Alessandro de' Pazzi de' Medici (ca. 1526) is penned by an unknown

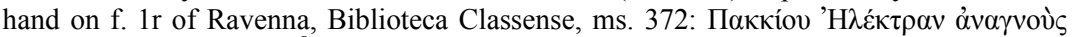

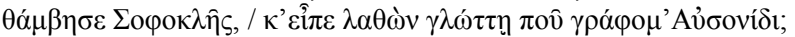




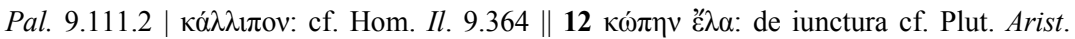

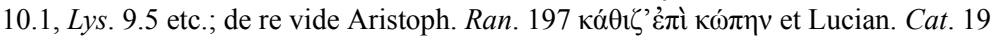

JULIUS: Quick, Charon, take me on board!

CHARON: Who are you, my dear friend?

JULIUS: Julius in person, formerly the pontiff reigning over the earth and the heavens.

CHARON: [All that was] in vain, but come in all the same.

JULIUS: What's your view of me here?

CHARON: A modest one.

JULIUS: No memory of my great deeds?

CHARON: Which ones?

JULIUS: I defeated the Flaminians, the Tuscans and the Venetians, and I sent the Gauls away from the Italian soil.

CHARON: Ah, you treacherous Spaniard, you Gaul and haughty Swiss, how is it that you all claim these territories for your own boundaries?

JULIUS: Through my wealth and my strategies I left Italy as I had found it when I first saw the light.

CHARON: All right, but let Minos judge you for all this later: now come on, my colleague, row with this oar.

The text has no title, nor - as is customary in the Poemata - does the context or the mise en page yield any hint towards a definition of its historical or literary Sitz im Leben. First of all, we can say that Dazzi displays his familiarity with the genre of the Greek epigram (in the course of his life he translated some ancient Greek epigrams into Latin, and even tried his hand at translating epigrams of Martial into Greek): ${ }^{9}$ in particular, the dialogic epigram, from Callimachus to Agathias, which is well at home in the seventh book of what is now the Palatine Anthol$o g y$, the most important repository of Greek funerary epigrams (see for example Anth. Pal. 7.64, 163-165, 307, 470, 524, 552, 603). The ancient Greek prototypes, however, seldom involve Charon himself, whereas the mythical ferryman is frequently invoked in other, non-dialogic texts (see Anth. Pal. 7.67-68, 365, 530). Dazzi is probably combining here a reminiscence of this ancient epigrammatic production with a clear allusion to the most obvious literary antecedent for a verbal exchange between Charon and other characters, namely Lucian's Dialogues of the

\footnotetext{
${ }^{9}$ See J. Hutton, The Greek Anthology in Italy to the Year 1800 (Ithaca, NY, 1935), 39 and 163 .
} 
Dead and - above all, given the special focus on a "tyrannos" and his post-mortem expectations - his Cataplus. ${ }^{10}$

In this respect, I believe this epigram ought to be added to the documentary material assembled both in the surveys on the fortune of Charon in modern times, ${ }^{11}$ and - more importantly - in the studies on Lucian's Nachleben in Italian humanism and in the Renaissance, where a conspicuous space is allotted to Lucian's influence on the "satirical" scenes set by Quattrocento writers in the Netherworld. ${ }^{12}$ The closest modern predecessor of Dazzi's epigram - in spite of the obvious differences in genre and general tone - is Giovanni Pontano's dialogue Charon, written in 1467 but unpublished until 1491: in Pontano's fiction, the ferryman plays a pivotal role, as his conversations with other divine characters (Hermes, Minos) and with the souls of the deceased (especially in the latter chapters) constitute the backbone of the entire work. ${ }^{13}$

The word हlo $\sigma \alpha i v \varepsilon$ (1. 3), however, adds another dimension to Dazzi's epigram: this imperative, though it also occurs in Lucian (Charon's $\varepsilon^{\prime} \mu \beta \alpha \imath v \varepsilon, \varepsilon \% \mu \eta \eta \theta$ in Cataplus 8 and 17), is an unmistakable allusion to Charon's order to the god Dionysus in the early scenes of Aristophanes'

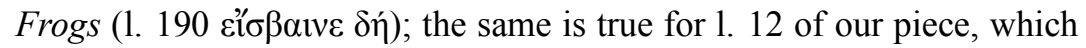
clearly recalls Charon's further exhortation to Dionysus to sit down and

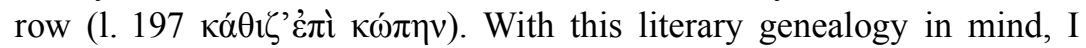
believe we can confidently assume that this text belongs to the satirical genre, all the more so as it stages a moment of difficulty and embarrassment for a very well-known and powerful man.

The identity of the speaker indicated as "Iu." is guaranteed by his

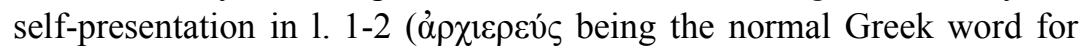
"pope" or "pontiff"), and particularly by the military achievements boasted in 1. 5-6: these are Pope Julius II's 1506 campaign in central

${ }^{10}$ Martina Tosello's full commentary of the Cataplus (dissertation University of Ferrara, 2018) is forthcoming.

${ }^{11}$ R.H. Terpening, Charon and the Crossing (London - Toronto, 1985), who does observe that in ancient Greek epigrams "the unit of greatest development is the address to the ferryman" (67), but does not find or name any single epigram in his survey of Charon's manifold presence in Italian literature from Dante to Marino (127-242).

12 D. Marsh, Lucian and the Latins (Ann Arbor, MI, 1998), esp. 42-75; L. Geri, A colloquio con Luciano di Samosata (Roma, 2011). A wider, if older, survey is to be found in R. Förster, Lukian in der Renaissance (Leipzig, 1886).

13 Marsh 1998 (as in n. 12), 129-143; J. Haig Gaisser (ed.), Giovanni Pontano, Dialogues, vol. 1 (Cambridge, MA - London, 2012); F. Tateo (ed.), Giovanni Pontano, Il dialogo di Caronte (Napoli, 2010); Id. (ed.), Giovanni Pontano, Dialogues latins, vol. 1 (Paris, 2018). 
Italy in order to recover Perugia, Forlì and above all Bologna ( $\Phi \lambda \alpha \mu$ ívioı must refer to the inhabitants of the regio Flaminia, a district stretching from Aesis to Ariminum, with the Via Flaminia crossing both Umbria and Romagna), ${ }^{14}$ the creation of the League of Cambrai which defeated Venice in 1509, and that of the Holy League which forced the French out of Italy in 1512. As for the taming of the Tovoкo1, it is less likely that the reference is to the regions of Tuscany and Umbria (Orvieto, Perugia) crossed by the papal troops in the aforementioned 1506 campaign: more likely, this is the 1512 Strafexpedition against the Tuscan supporters of the French (and of the Council of Pisa summoned in order to deny Julius' authority). The most famous episode of this expedition - which Guicciardini (and Soderini) considered a true act of war against the freedom of Florence $^{15}$ - was the destruction of Prato, perpetrated by Giovanni de' Medici (soon to become Pope Leo X) in order to terrify the Florentines and ease the restoration of the Medici authority in town. Incidentally, these chronological repères point to a date after 1512 and thus make it unlikely that the epigram should belong to the tradition of scoptic in mortuum poems written before the death of the targeted person. ${ }^{16}$

\section{Dazzi's epigram: satirical elements}

Dazzi's satire is of course no open or wild mockery of the deceased (no final condemnation is expressed by Charon, and the merits stated by the pope are never overtly contradicted), and one could well think that it is only motivated by the wish to implicitly present the new Medici pope as significantly superior to his predecessor - Dazzi had followed this path

14 See J. Weiss, "Flaminia", in Paulys Realencyclopädie der classischen Altertumswissenschaft, vol. 6.2 (Stuttgart, 1909), 2492-2493. See also the (encomiastic) reference to Julius' conquest of Bologna in Dazzi's own Panegyricum ad Cosmum Paccium, 545-557 (Poemata (as in n. 5), 26).

15 See E. Lugnani Scarano (ed.), Francesco Guicciardini, Storia d'Italia (Torino, 1987), 962-967 (10.6): “Avendo nell'animo che innanzi a ogni altra cosa si movesse la guerra contro a' fiorentini, per indurre a' voti de' confederati quella republica, rimettendo al governo la famiglia de' Medici, né meno per saziare l'odio smisurato conceputo contro a Piero Soderini gonfaloniere."

16 See e.g. Machiavelli's epigram on Pier Soderini in Rime varie 15: Corsaro, Cosentino et al. 2012 (as in n. 1), 283-284, with A. Corsaro and N. Marcelli's notes. 
in other passages of his Latin verse. ${ }^{17}$ Yet, a number of paradoxical elements stand out for their weight:

1. After his death, Julius is not directed to the Christian Paradise but rather to Hades: he does not knock on St. Peter's door, but crosses the Acheron.

2. Despite his power and status, Julius is not recognised by Charon, and has to state his own identity.

3. In presenting himself, Julius claims his former power on earth and sky, but Charon deems this pointless or vain (1. $3 \mu \alpha \dot{\psi} \psi)$.

4. Answering Julius' specific question, Charon candidly admits that there is no memory (or talk) of Julius' great deeds.

5. Julius therefore has to recall one by one his military victories, and, answering Charon's lament over the sad fate of Italy, ${ }^{18}$ he proudly recalls his decisive contribution (by thought and money, 1.9) to the wealth and power of the Holy See and of Italy in general, which he claims to have restored to the grandeur of 1443, the year of his birth (not only, that is, long before the Italian expedition of Charles VIII, but also the very year in which Pope Eugenius IV came back to Rome and restored his control over the Catholic Church after a ten-year exile).

6. No final verdict is pronounced on Julius (a pope of the Roman Church!), but he is assigned to Minos for judgment.

7. Julius is invited to row, as if being a colleague of Charon: the adjective ónó $\tau \varepsilon \chi v o \varsigma$ is here a subtle allusion to Giuliano Della Rovere's youthful service as a ferryman in his hometown Albisola (Liguria), mentioned by Matteo Bandello, among others. ${ }^{19}$

${ }^{17}$ I believe the Latin epigram on p. 131 of Dazzi's Poemata should be traced back to the comparison between Julius II and his successor: "Vicit Alexander consulti gesta Philippi, / rursus Alexandri vicit Iulus opus: / at Medices tanto superavit (...〉 Iulum, / quanto nobilior quam scolopendra leo" ( $\ldots$... stands for a lacuna, but the "leo" metaphor is evident enough).

${ }^{18}$ Charon's invocation involves not only the French, but also the Spaniards, i.e. the kingdom of Naples, which had been putting pressure on the southern border of the Stato della Chiesa ever since the mid-fifteenth century (the Spaniards' power was feared by the Medici themselves, whom they helped recover control over Florence), and the Swiss troops that fought the French and flooded Italy all the way down to Milan and Verona: see C. Shaw, Giulio II (Torino, 1995), 178-179. Cf. Dazzi's own Greek epigram on the Italian expedition of Charles V (Poemata (as in n. 5), 121-122), expressing the bitter concern that

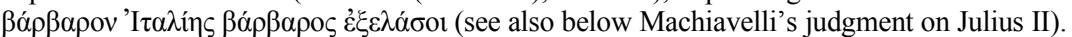

${ }^{19}$ Matteo Bandello, Novelle 1.31: "Giulio secondo pontefice, ancor che di bassissima gente fosse disceso e non si vergognasse spesse fiate dire che egli da Arbizuola, villa del Savonese, avesse con una barchetta più volte, quando era garzone, menato de le cipolle a vendere a Genova"; see D. Conrieri, "Giulio II e i letterati", in G. Rotondi Terminiello, G. Nepi (ed.), Giulio II papa, politico, mecenate (Genova, 2005), 91-116, at 108. Further 
Several of these elements show analogies with the spirit and the atmosphere of Lucian's dialogues: the humiliation of the once powerful man, the levelling of man's fate in the face of death, the indifference of the Underworld to the priorities and prejudices that haunt the world of the living. ${ }^{20}$ Only point 1 opens a specific, "modern" dimension to this satire, and one not unknown to previous humanistic reception of the ancient Greek heritage: in Italian Renaissance literature "Charon may serve as either a representative figure of the Hades of secular heroic poetry or a symbol of the hell of Christian epic," 21 the latter option being most clearly embodied by the violent image of the ferryman in the third canto of Dante's Inferno. And yet, the fact that Julius meets Charon does not necessarily imply that Dazzi intended to present him as a sinner to be assigned by Minos to the right girone, as would be the case in Dante's fiction: ${ }^{22}$ first of all, this is not Julius' own expectation in the epigram, for he implicitly claims that he should be rewarded for his merits; secondly, if we consider Pontano's Charon, for example, we see that the mythical ferryman comes face to face with people such as Socrates or Christ, which demonstrates that Charon and the crossing stand as a simple antonomasia for the Beyond, for the single place where all the dead will end up sooner or later. Be that as it may, because Julius is the legitimate (if pro tempore) holder of the keys of St. Peter, a humanistic fiction that joins him to the ferryman of the pagan Underworld is obviously ironic.

testimonies to Julius' humble origins are mentioned by P. Fabisch, Iulius exclusus e coelis (Münster, 2008), 53, and by S. Seidel Menchi (ed.), Iulius exclusus, in Desiderii Erasmi Opera omnia, vol. 1.8 (Leiden, 2012), 1-297, at 213 (ad 1. 129).

${ }^{20}$ See the question $\tau i ́ v \varepsilon \varsigma$ $\dot{\sigma} \sigma \tau \dot{\varepsilon}$ addressed by Minos to Alexander and Hannibal (Dial. mort. 25.1) and by Menippus to Nireus and Thersites (Dial. mort. 30.1); see also Dial. mort. 29, with Diogenes poking fun at Mausolus' claims of his past greatness (29.1

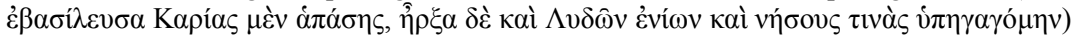
and at his pleas for a corresponding reward.

${ }^{21}$ Terpening 1985 (as in n. 11), 206.

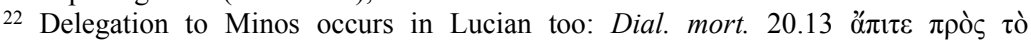

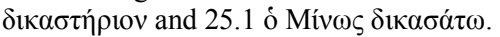




\section{Anti-papal satire}

The most learned readers of Dazzi's epigram might have recalled a specific section in Pontano's Charon, namely the conversation between Minos and Mercurius on the plight of the Italian states: ${ }^{23}$

MINOS: Quid autem portenta [scil. celestial signs] sibi ista volunt?

MERCURIUS: Pestem significant et bellum.

MinOs: Bellumne? A quibus?

MERCURIUS: A sacerdotibus.

MINOS: Ab iis igitur inferetur bellum, quos maxime deceret pacis auctores esse?

MERCURIUS: Verbis pacem, coeterum rebus bellum petunt.

MiNOS: Inferendi belli quaenam causa?

MERCURIUS: Ampliandi regni cupiditas.

MINOS: Horum igitur malorum causa est avaritia?

MERCURIUS: Ea ipsa; quae in hoc hominum genere quanta sit dici vix potest.

Minos: Videlicet obliti sunt iustitiae.

MERCURIUS: Quae, obsecro, haberi potest iustitiae ratio ubi regnat avaritia?

In Pontano's dialogue this exchange, which leads to further considerations on the inadequacy of the Italian states to stop a persisting and irrational state of mutual warfare ("Interiit Romana virtus" exclaims Minos, complaining that Rome and Italy are now devoid of ingenia and viri) and on the constant threat of the Turks (the mythical character of Aeacus intervenes in the dialogue, lamenting the slavery of Greece), refers to the deplorable military campaigns of the popes - probably Paul II (1464-1471) and Sixtus IV (1471-1484) - not against the Turks, but in a number of Italian conflicts whose only reason is to expand the worldly (rather than the spiritual) power of the Church.

Even if Pontano here refers to his own time, the political problem he spells out - the participation of the Church and the popes ("sacerdotes") in armed conflicts against other Christian rulers and states - lies at the heart of numerous polemical writings directed precisely against Pope Julius II, universally targeted as the most belligerent pope of his time. While part of a tradition of anti-clerical literature dating from the reign

${ }^{23}$ Tateo 2018 (as in n. 13), 37 (Charon, ch. 38). 
of Julius' predecessor Alexander VI Borgia, ${ }^{24}$ the vast number of polemical pamphlets, satirical dialogues and epigrams, cartelli stampati, cruel epitaphs, pasquinate, and verses in both Latin and Italian directed against Julius II and his worldly ambition influenced both the high-brow literati and the illiterate masses. ${ }^{25}$ "Contra papa Julio sono stati facti un milion di versi latini di gran maldicentia, e altrettanti vulgari," wrote the humanist Mario Equicola in a letter of 21 March 1513, one month after the pope's death, in a period when violent criticism exploded throughout Italy and Europe. ${ }^{26}$

Many of these pieces originated and circulated in the cities that had fallen victim to Julius' military campaigns, above all Bologna, Ferrara, and Venice; others were written in England and France, when Julius turned these countries into enemies of the Roman Church - a remarkable cycle of epigrams and satires stems from the pen of the German humanist Ulrich von Hutten. ${ }^{27}$ This material was not isolated, however: it was constantly countered by a positive, indeed enthusiastic image of the pope as the heir to his namesake Julius (Caesar), and as the restorer of the Golden Age and of Italian freedom, an image asserted in numerous enthusiastic epigrams and propagandistic writings. ${ }^{28}$ It is interesting to see that much of the debate between friends and foes of Julius revolved precisely around the issues that lie at the heart of Dazzi's epigram: the

${ }^{24}$ O. Niccoli, Rinascimento anticlericale (Roma - Bari, 2005), 49-78: some topical writings, such as the Epistola Luciferi, circulated since the late Middle Ages and were adapted to the contemporary popes.

${ }^{25}$ Niccoli 2005 (as in n. 24), 79-95; M. Rospocher, Il papa guerriero (Bologna, 2015); Fabisch 2008 (as in n. 19), 33-39 (the rest of Fabisch's inquiry is focused on the Gallican polemic against Julius II and his ecclesiastical policy).

${ }^{26}$ Niccoli 2005 (as in n. 24), 84; Rospocher 2015 (as in n. 25), 171-73.

${ }^{27}$ E. Böcking (ed.), Ulrich von Hutten, Schriften, vol. 3 (Leipzig, 1862), 260-270: the epigrams insist on the comparison with St. Peter and on Julius' avidity and fondness for war. See Fabisch 2008 (as in n. 19), 330-332; H. Wulfert, Die Kritik an Papsttum und Kurie bei Ulrich von Hutten (1488-1523) (Münster, 2009), 85-96.

28 E.g. the 1504 De officio liber by Giovan Francesco Poggio (Bracciolini's son), containing a sort of apotheosis of Julius II, the defender of Italy and of the plenitudo potestatis of the Holy See (see Seidel Menchi 2012 (as in n. 19), 91-93); or the 1508 De aurea aetate of Aegidius of Viterbo for the idea of the palingenesis promoted by Julius (Rospocher 2015 (as in n. 25), 45-49). See also the material assembled by Rospocher 2015 (as in n. 25), 93-140, for Julius' attitude as a peacemaker (!), and 141-170 for Julius as the liberator of Italy. The literary tradition of encomiastic epigrams and poems for Julius II is admirably explored by V. Cian, review of "L. Pastor, Geschichte der Päpste seit dem Ausgang des Mittelalters, vol. 3 (Freiburg, 1895)", Giornale storico della letteratura italiana 29 (1897), 403-452, at 442-448. 
extent of his military achievements and his contribution to the liberation of Italy from foreign armies.

Both leading spirits of sixteenth-century political theory, albeit fascinated by Julius II and concurring in praise for his constant concern with the increment of the Catholic Church and with the freedom of Italy, ${ }^{29}$ criticised him in some respects: Niccolò Machiavelli for bringing foreign troops in the peninsula (we find in him a noteworthy mention of the Swiss army, whose help was paramount in the fight against the French: see 1.7 of our epigram), ${ }^{30}$ and Francesco Guicciardini for shedding the blood of other Christians rather than taking care of the edification of their souls. ${ }^{31}$ Indeed, as early as March 1513 Guicciardini entertained the hope that Julius' successor would be a "good" pope, "uno uomo buono e che avessi tanto interesse nel buono essere di Italia che gli avessi causa di pensare a conservarla e non a fare di nuove revoluzione." 32 This hope was shared by many, including Erasmus of Rotterdam, ${ }^{33}$ the famous Cretan philologist Markos Mousouros in his 1513 Ode to Plato (dedicated to Leo X as a restorer of peace and of Greek studies in Italy), ${ }^{34}$ and by Dazzi himself, who in his Virbius urged

${ }^{29}$ Machiavelli, Principe 11.15: "Lui fece ogni cosa per adcrescere la Chiesa e non alcuno privato", and Lugnani Scarano 1987 (as in n. 15), 866 (9.9): "Per non essere l'imprese sue mosse da interessi particolari ma da mero e unico desiderio della libertà d'Italia"; 1114 (11.8): "Pensava assiduamente come potesse o rimuovere d'Italia o opprimere con l'aiuto de' svizzeri, i quali solo magnificava e abbracciava, l'esercito spagnol, acciò che, occupato il regno napoletano, Italia rimanesse (queste parole uscivano frequentemente dalla bocca sua) libera da' barbari."

${ }^{30}$ F. Bausi (ed.), Niccolò Machiavelli, Discorsi sopra la prima deca di Tito Livio (Roma, 2001), 88: 'E quando ne' tempi nostri ella [scil. la Chiesa] tolse la potenza a' Viniziani con l'aiuto di Francia, dipoi ne cacciò i Franciosi con l'aiuto de' Svizzeri" (the Swiss mercenaries appear as less dangerous in ch. 13 of the Principe). On the evolution of the figure of Julius II in Machiavelli see M.G. Blasio, "Machiavelli, Giulio II, il principato ecclesiastico", in F. Cantatore, M. Chiabò et al. (ed.), Metafore di un pontificato (Roma, 2010), 29-43.

${ }^{31}$ Lugnani Scarano 1987 (as in n. 15), 1095 (11.8): (Julius II is honoured amongst those who believe) "che sia più officio de' pontefici aggiugnere, con l'armi e col sangue de' cristiani, imperio alla sedia apostolica che l'affaticarsi con lo esempio buono della vita e col correggere e medicare i costumi trascorsi, per la salute di quelle anime." See also ibid., 961 (10.6), where Julius is termed "l'autore e cagione principale di più lunghe e maggiori calamità di Italia". On Julius II between Machiavelli and Guicciardini see Conrieri 2005 (as in n. 19).

32 P. Jodogne (ed.), Francesco Guicciardini, Le lettere, vol. 1 (1499-1513) (Roma, 1986), 365: Lettera ai Dieci di Balia, 3-6 March 1513, 1. 207-209.

${ }^{33}$ Fabisch 2008 (as in n. 19), 203.

${ }^{34}$ N.G. Wilson (ed., tr.), Aldus Manutius, The Greek Classics (Cambridge, MA, 2016),

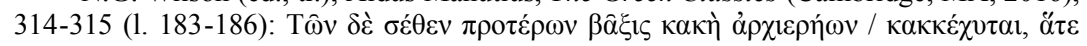


Pope Leo to pursue the engagement of Julius by radically new means, namely not with military but with spiritual weapons. ${ }^{35}$

On a more popular level, a prose text called Lettera fenta che Iesu Christo la manda a Julio II in questo anno 1509 portrays Christ warning the pope about the danger of eternal damnation, if he fails to atone for his numerous sins, including rapacity and bloodthirstiness. ${ }^{36}$ The largely anonymous Latin and Italian epigrams in morte Iulii collected by the Venetian chronicler Marin Sanudo ${ }^{37}$ insist on the pope's evil ambition, on his pernicious and unceasing belligerence, on his self-image as omnipotent (stronger than Rome, than St. Peter, than Christ himself: see 1. 2 of Dazzi's piece): ${ }^{38}$ a humorous Italian ottava called "Dialogo di papa Julio" shows that because of Julius' terrifying negative force no single place is capable of containing his soul, neither Hell nor Paradise; ${ }^{39}$ a Latin couplet imagines him as the guardian of Hell: "Iulius arma ciens,

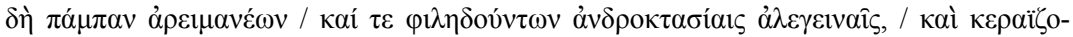

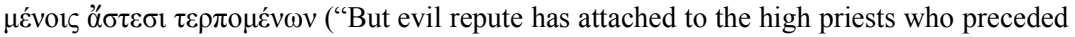
you because they were quite crazed with warlike instinct, took pleasure in dire slaughter of men and delighted in the destruction of cities"). See L. Ferreri, L'Italia degli umanisti. I. Marco Musuro (Turnhout, 2014), 146; R. Dijkstra, E. Hermans, "Musurus' Homeric Ode to Plato and his Requests to Pope Leo X", Akroterion 60 (2015), 33-63, at 57.

35 Virbius, 683-691 (Poëmata (as in n. 5), 165; ms. Ricc. 970, f. 20r): “Ast ubi per varias clades Martisque ruinas / conversis regum studiis tentavit Iulus / victores Itala Gallos depellere terra: / cura datur magni magno tibi maxima belli. / Humani quod iuris erat, mentisque manusque / confectum. Vires animi, prudentia, virtus, / nil reliqui fecere sibi, et si certa daretur / vincendi spes, certa fuit, sed plurima belli / sors habet et dubio pendet victoria casu"; see also 1. 898-901 (Poëmata (as in n. 5), 172; ms. Ricc. 970, f. $25 \mathrm{v}$ ): "Denique pace frui per te conceditur omnes / auctorem te pacis habent. Tu reddis honori / deiectos olim proceres. Tu, si quid Iulus / consuluit gravius, relevas"; and the explicit 1. 967-968 (Poemata (as in n. 5), 174; ms. Ricc. 970, f. 27r): "Salve iterum, felixque orbi patriaeque tuisque / haeredem magni referas Augustus Iuli." See however 1. 718720 (Poemata (as in n. 5), 166; ms. Ricc. 970, f. 21r), where Dazzi recalls that Giovanni de' Medici had been chosen as the future pope by Julius himself on his deathbed.

${ }^{36}$ Niccoli 2005 (as in n. 24), 86-88.

${ }^{37}$ Marino Sanuto, I Diarii, vol. 15 (Venezia, 1887), 561-565: see Rospocher 2015 (as in n. 25), 253-256.

${ }^{38}$ See already the 1510 anonymous Bolognese sonnet quoted by Rospocher 2015 (as in $\mathrm{n}$. 25), 111: "Iove nel cielo può tuto e Iulio in tera / e l'uno e l'altro [h] forza in tera e in cielo."

${ }^{39}$ Sanuto 1887 (as in n. 37), 563: "Dunque ove sei? - Pensa, ridotto ho Dio / che non sa dar albergo al spirto mio" (see Rospocher 2015 (as in n. 25), 254-255). A similar "suspension" of Julius' soul between Hell and Paradise is imagined in Giacomo Zili's Italian epitaph in Bologna, Biblioteca Universitaria, ms. 779, f. 106v (partly edited by Rospocher 2015 (as in n. 25), 203-204): see 1. 1-4 "Iulio pastor morto et sepulto è / et il spirito suo se n'è andato de là; / dove congionto fia el non se sa / ma per l'opre sue pensare se dé." 
parvus cui maximus orbis / visus erat, nigri ianitor orbis erit."40 These texts, however, respond to a radically opposite tradition depicting Julius as the restorer of St. Peter's authority after the dark reign of Alexander VI; ${ }^{41}$ during the Roman Carnival of 1513, just a few days before the Pope's death, Giovanni Jacopo Penni's cantare celebrated the "Pastore Julio felice, / ch'alla Chiesa lasciò tranquillo stato, / benché qualcuno a torto mal ne dice."42

Dazzi's epigram has little of the cruel vis inherent in Sanudo's lampoons, and its learned texture remains on a different level from the more "popular" satires or pasquinate; furthermore, if the use of Latin has already been suspected as a serious (and intended) obstacle to the dissemination of dangerous humanist satires, ${ }^{43}$ the choice of Greek seems an artificial way to make the understanding of this verse even more difficult, and de facto accessible to just a few learned scholars: the "comunicazione a 'circuito chiuso' della Respublica literaria". ${ }^{44}$ Nonetheless, it is clear that our epigram shares by and large the same cultural humus with the less "refined" texts that were current in contemporary Italy.

\section{The Iulius exclusus}

Dazzi's poem would be of more limited interest if it did not parallel a more celebrated, contemporary work on the death of Julius II: the anonymous prose dialogue Iulius exclusus e coelis, now commonly attributed to Erasmus of Rotterdam. In this witty and harsh text, the soul of Julius II, escorted by his Genius, knocks on the gates of heaven, and

40 Sanuto 1887 (as in n. 37), 562.

41 See the sonnet in V. Marucci, A. Marzo, A. Romano (ed.), Pasquinate romane del Cinquecento, vol. 1 (Roma, 1983), 53-54, no. 65 (in a slightly different form in Sanuto 1887 (as in n. 37), 565; see Rospocher 2015 (as in n. 25), 165-166; Niccoli 2005 (as in n. 24), 85): "Io fui Iulio pontefice romano, / che trovai Pietro in vincula legato / e senza chiave e col manto squarciato, / sotto a' figlioli d'un pastor marrano. / Pietro sligai di carcere pian piano, / e [così] cominciai a porgli el manto / e, se morte non era, l'avrei dato / de tutto el grege suo le chiave in mano."

42 See A. Ademollo, Alessandro VI, Giulio II e Leone X nel Carnevale di Roma (Firenze, 1886), 50. Earlier in the same cantare Penni (ibid., 40) mentions an obelisk inscribed with Greek, Latin, Hebrew and Chaldaean letters that mean "Iulio secundo Italiae liberatori, [...] ac scismati [sic] expulsori”.

43 See Niccoli 2005 (as in n. 24), 79.

${ }^{44}$ Rospocher 2015 (as in n. 25), 254. Both Erasmus and Budé (when criticising Julius) notoriously resorted to this artifice: see Seidel Menchi 2012 (as in n. 19), 125. 
attempts in vain to convince St. Peter to admit him into Paradise. Followed by a turba of his former adepts and soldiers, and equipped with an unprecedented arrogance, Julius tries to impose his authority on Peter by vaunting his military merits and by perversely defending even his public and private crimes (from cruelty and avidity to pederasty) as falling under the plenitudo potestatis of the Roman pontiff, and thus remaining exempt from condemnation or punishment. In doing so, he ridicules both the apostolic virtues claimed by St. Peter as essential for admission, and the ideals of evangelic poverty allegedly preached by his Gallican opponents during the Council of Pisa of 1512. Julius' account of the contemporary Church constitutes one of the most sarcastic attacks on papal authority before Luther - indeed, the very fact that this dialogue was published in Mainz in the summer of 1517 marks a sinister coincidence, and one that changed its subsequent fate and inevitably altered and blurred the traces of its history.

After centuries of debate on the authorship of this dialogue, ${ }^{45}$ Silvana Seidel Menchi has demonstrated on a sound philological basis that Erasmus of Rotterdam - despite his repeated claims to the contrary indeed wrote the Iulius exclusus during his stay in Cambridge; ${ }^{46}$ in her reconstruction, the dialogue's long route from the earliest manuscript to the first print in 1517 did not pass through Italy, as some scholars had previously argued. ${ }^{47}$ In other words, Erasmus' Iulius was a totally "Northern European" product, which owing to the simultaneous explosion of Luther's Reform was ipso facto banned from Italy in later decades. $^{48}$

${ }^{45}$ Culminating in the difficult hypothesis of the otherwise very learned monograph by Fabisch 2008 (as in n. 19), which does allow some role for Erasmus but still assigns a pivotal role to the "für die Zeit des Humanismus typische Zusammenarbeit" (485) with Hutten and Beatus Rhenanus, and to the influence of the Gallican environment, particularly the Parisian court poet Fausto Andrelini, who figured as the author ("F.A.F.", Faustus Andrelinus Foroliviensis) in the 1517 editio princeps.

${ }^{46}$ See also, more succinctly, the introduction to S. Seidel Menchi (ed.), Erasmo da Rotterdam, Giulio (Torino, 2014).

${ }^{47}$ Seidel Menchi 2012 (as in n. 19), 58-60 (see for the opposite opinion, claiming a Roman transit of Hutten and the manuscript, Fabisch 2008 (as in n. 19), 338-342 and 409-411).

${ }^{48}$ Seidel Menchi 2012 (as in n. 19), 120-121; Ead., Sulla fortuna di Erasmo in Italia 1520-1580 (Torino, 1987). I agree with Seidel Menchi that Andrea Guarna's Simia (1516) is no real clue as to the Italian circulation of Erasmus' work - see however S. Valerio, "Dialogare alle soglie del Paradiso", in A. Steiner-Weber (ed.), Acta Conventus NeoLatini Monasteriensis (Münster, 2015), 572-581, at 578. 


\section{Dazzi and the Iulius}

Does Dazzi's epigram show significant analogies with the Iulius? To my mind, more so than any other extant literary work. If we look back at the satirical elements listed above, we find several common points: ${ }^{49}$

[1. Erasmus' dialogue is set in Heaven, so that the Hades scenery and the contact with Charon obviously do not apply]

2. Despite his power and importance, Julius is not recognised by Charon and has to state his own identity. In the Iulius:

1. 11 (Julius): "Heus heus! Aperite hoc actutum aliquis ostium!" (cf.

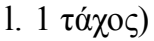

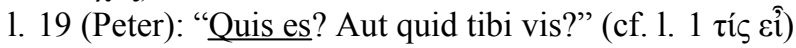

1. 22 (Peter): "At tu mihi prius exponito quisnam sis"

1. 38 "Nam ego si nescis sum Iulius ille Ligur; et agnoscis ni fallor duas literas P.M., nisi omnino literas non didicisti' (cf. 1.1 'Iov́ $\lambda$ ıo av่tós)

3. In presenting himself, Julius claims his former power on earth and sky, but Charon deems this pointless or vain. In the Iulius:

1. 88-89 (Peter): "Hae fores tibi sunt aliis armis expugnandae"

1. 96 (Peter): "Si quos olim istis fumis territasti, nihil ad hunc locum" (cf. $1.3 \mu \alpha ́ \psi)$

1. 108: "Ni merita narras, inquam, nihil agis"

1. 984: "Me Iovem fulmine concutientem omnia [...] esse praedica-

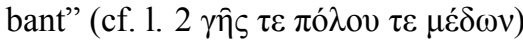

4. Answering Julius' specific question, Charon candidly admits that there is no memory of (or consideration for) Julius' great deeds. In the Iulius:

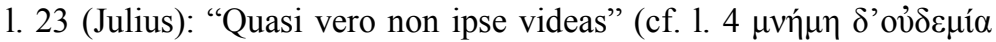
$\mu \varepsilon \gamma \dot{\alpha} \lambda \omega v ;)$

1. 206 (Peter): "Quoniam mihi nova et inaudita sunt omnia quae narras, quaeso veniam hanc meo des vel stupori vel imperitiae" (cf. 1. 5

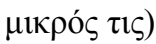

5. Julius therefore has to recall one by one his many military victories, and, answering Charon's lament over the sad fate of Italy, he proudly

${ }^{49}$ All citations from the Iulius exclusus are taken from the edition by Seidel Menchi 2012 (as in n. 19). 
recalls his decisive contribution (through thought and money, 1. 7) to the wealth of the Holy See and of Italy in general, which he claims to have restored to the greatness of the year of his birth. In the Iulius:

1. 157 (Julius): "Nam multis officiis - sic enim vocant - novis repertis, non mediocriter auxi fiscum pontificium" (see until 1. 165); 1. 183: "moriens reliqui quinquagies centum milia ducatorum" (cf. 1.9

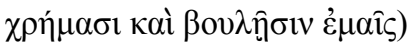

1. 165-171 (see also 1. 864-867): "Et ut ad maiora veniam, Bononiam a Bentivolis occupatam Romanae sedi restitui. Venetos ante invictos omnibus Marte contudi. Ferrariae ducem, diu male vexatum bello, propemodum in nassam illexeram. Conciliabulum schismaticum simulato contra concilio feliciter elusi et clavum quod dici solet clavo pepuli. Postremo Gallos tunc orbi formidabiles universo ex universa Italia deturbavi, deturbaturus et Hispanos - nam huc ibam -, nisi me

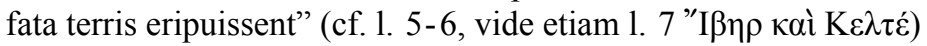

1. 606-607: "Totamque illam Barbarorum fecem Italia submoverem"

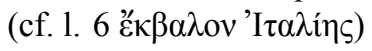

[6. Erasmus' dialogue is set in Heaven, so that the Hades scenery and the delegation to Minos obviously do not apply]

7. Julius is invited to row the boat, as if co-worker and colleague of Charon: the adjective ó $\mu$ ó $\tau \chi \chi v o \varsigma$ is here an overt allusion to Giuliano Della Rovere's youthful service as a ferryman in his hometown Albisola. In the Iulius:

1. 122 (Julius): "Quanquam indigna res Iulium illum omnibus antehac invictum nunc Petro cedere, ut ne quid aliud dicam piscatori ac pra>ene mendico, tamen uti cognoscas cuiusmodi contemnas principem, audi iam paucis. Principio Ligur sum, non Iudaeus ut tu. Cum quo mihi vel hoc esse commune doleo, quod naviculator aliquando fuerim" (cf. 1. 12 ó $\mu$ ó $\varepsilon \chi \chi \nu \varsigma)$

1. 128 (Genius): "Nihil est quod graviter feras. Nam hic quoque permultum interest, quod hic victus parandi gratia piscabatur, tu ad stipem exiguam scalmum remis subigebas"

\section{Final thoughts}

It is true that the general idea of a conversation between a dead pope's soul and a guardian of the Netherworld did circulate in humanistic writings, and that from the Epistulae Luciferi and Dante's Inferno all the way down to the Roman pasquinate, this kind of paradoxical post- 
mortem satire existed in Italian and European anti-papal literature. However, the aforementioned analogies between Dazzi's poem and Erasmus' dialogue are quite specific, they do not overlap with other known literary products of this kind, and can hardly be regarded as entirely coincidental.

If we believe in a textual contact, we can theorise that Dazzi read Erasmus' Iulius and re-elaborated some aspects of it in Greek: this, however, would contradict our dating of the epigram to the spring of 1513 (see above); even if we admitted a later dating, there would remain the fact that Dazzi felt no sympathy for the Lutheran movement, under whose stigma the Iulius circulated since its publication in 1517.50

On the other hand, we know that during the years of Julius' pontificate, and especially during his Italian stay of 1506-1509 (Turin, Florence, Rome, Venice), Erasmus - the spectator of Julius' grand triumphal ceremonies in Bologna - had grown acquainted with some elements of the Italian anti-papal polemic. In recent times, Ottavia Niccoli has advocated for Erasmus some knowledge of the Italian satirical literature against Julius, ${ }^{51}$ and Sebastiano Valerio has brought interesting arguments in support of Erasmus' familiarity with Galateo's Eremita. ${ }^{52}$ Niccoli has also stressed that a dialogue on Pope Leo X's turbulent access to Paradise (written upon his death in 1523: "Corri, Pietro, perché un bussa forte") is preserved among the pasquinate, and can hardly be independent of Erasmus' model..$^{53}$

Of course, the Iulius exclusus was not necessarily inspired by a Greek epigram or other model, for Erasmus had long been familiar with the genre of ancient satire, and with Lucian's dialogues in particular; furthermore, Erasmus' target in the Iulius was less Julius II's character or political ambitions than the corruption of the Roman Church, a topic that was inconceivable for Dazzi. Still, in light of the above, it is tempt-

${ }^{50}$ See Rüdiger 1897 (as in n. 4), 66.

${ }^{51}$ See Niccoli 2005 (as in n. 24), 88-91: "L'autore dello Iulius o del Sileni Alcibiadis non aveva certo bisogno di trovare la sua ispirazione nella Littera fenta o nella Epistula Luciferi: ma si trattava di testi che egli poteva avere conosciuto, almeno il secondo, e sentiti consentanei alle proprie posizioni; e che comunque, in forma senza dubbio più modesta, ne anticipavano alcuni aspetti." The pasquinade in praise of Julius II's military achievements (above, n. 41) also makes for an inspiring comparison with the Iulius, where St. Peter plays such a dramatically different role.

52 Valerio 2015 (as in n. 48).

${ }_{53}$ Marucci et al. 1983 (as in n. 41), 230-231, no. 242 (see also no. 207 and 209 with dialogues in the Underworld or involving St. Peter). If this is true, then Seidel Menchi's idea of a limited circulation of the Iulius in Italy might need some revision. 
ing to theorise that beyond the obvious ancient sources that have been evoked for the Iulius (Lucian, again, and Seneca's Apocolocyntosis), ${ }^{54}$ there might be a broader Italian background to the dialogue. ${ }^{55}$

Is it really far-fetched to surmise that, through some unknown channel, ${ }^{56}$ Dazzi's fiction reached the Dutch scholar, further inspired his creative vein, and stimulated the idea of a more radical satire in which the pagan "humanistic" attire of Charon and Acheron would leave the stage to a stern confrontation between the terrible pope and the eternal symbol of genuine Christian values, St. Peter? After all, it is known that Erasmus often referred to the dialogue - whose authorship he constantly denied - by the Greek title 'O 'Iov́ $\lambda$ ios. ${ }^{57}$

Be that as it may, Dazzi's epigram can at the very least remind us that the high-brow tradition of Lucianic satire and the popular tradition of papal mockery underwent mutual exchanges and cross-fertilizations, and that such a pure product of learned humanism as Erasmus' Iulius gave to and took from a multiform, international and multilingual background.

\author{
Università Ca' Foscari Venezia \\ f.pontani@unive.it
}

${ }^{54}$ See Fabisch 2008 (as in n. 19), 309-325 (expanding on the studies and imitations of Lucian in Erasmus, Thomas More and Ulrich von Hutten in the years around 1516-1517), and R. Roncali, 'L'Apocolocyntosis nel Cinquecento: da Erasmo all'elezione di Enrico IV", Quaderni di storia 1 (1980), 365-379, at 368-370.

55 This is incidentally one of the arguments behind the otherwise unlikely attribution of the Iulius to the English diplomat Richard Pace, who lived in Italy between 1509 and 1514: see C. Curtis, Richard Pace on Pedagogy, Counsel and Satire (dissertation Cambridge, 1996), 255; Ead., "The Best State of the Commonwealth", in A. Brett, J. Tully (ed.), Rethinking the Foundations of Modern Political Thought (Cambridge, 2006), 93-112, at 107-110.

56 While we have some traces in Erasmus' correspondence of his contacts with other European scholars, there is little that might bring him close to Dazzi or to the Florentine milieu.

57 See Seidel Menchi 2012 (as in n. 19), 14, n. 45 ("the Greek acts as a convenient encoding device"), and 72 . 